\title{
Measuring and Evaluating the Effectiveness of Active Citizenship Education Programmes to Support Disadvantaged Youth
}

\author{
Liyuan Liu ${ }^{1}$ * , Steven Donbavand ${ }^{2}$, Bryony Hoskins ${ }^{1}$, Jan Germen Janmaat ${ }^{3}$ and Dimokritos Kavadias ${ }^{4}$ \\ 1 Department of Social Science, University of Roehampton, London SW15 5SL, UK; \\ bryony.hoskins@roehampton.ac.uk \\ 2 Institute of Education, Social and Life Sciences, University of Chichester, Chichester PO19 6PE, UK; \\ s.donbavand@chi.ac.uk \\ 3 Institute of Education, University of College, London WC1E 6BT, UK; g.janmaat@ucl.ac.uk \\ 4 Department of Political Science, Vrije Universiteit Brussel, 1050 Brussel, Belgium; \\ dimokritos.kavadias@vub.be \\ * Correspondence: drliyuanliu@hotmail.com
}

Citation: Liu, Liyuan, Steven Donbavand, Bryony Hoskins, Jan Germen Janmaat, and Dimokritos Kavadias. 2021. Measuring and Evaluating the Effectiveness of Active Citizenship Education Programmes to Support Disadvantaged Youth Social Sciences 10: 394. https:// doi.org/10.3390/socsci10100394

Received: 20 September 2021 Accepted: 22 September 2021 Published: 15 October 2021

Publisher's Note: MDPI stays neutra with regard to jurisdictional claims in published maps and institutional affiliations.

Copyright: (c) 2021 by the authors. Licensee MDPI, Basel, Switzerland. This article is an open access article distributed under the terms and conditions of the Creative Commons Attribution (CC BY) license (https:// creativecommons.org/licenses/by/ $4.0 /)$.

\section{Introduction}

The current Special Issue has been inspired by the Seventh Annual Conference on Citizenship Education that was held in Roehampton University London, on 26-27 September 2019. This conference explored how citizenship education can promote young people's civic and political engagement, particularly those of disadvantaged backgrounds. Discussions focused on the effectiveness of diverse formal and informal educational programmes and activities across Europe. Contributions to the conference drew on various theoretical arguments, utilised a wide range of methods and techniques, and concluded with practical strategies. As editors, we prioritised the contributions of early career researchers and those that highlight helpful strategies to improve social equality and provide equitable distribution of learning resources among underprivileged groups. After two years' close collaboration among academic editors, journal editors and authors, this Special Issue is finally released in 2021 with seven papers.

This editorial aims to inform a wide range of stakeholders, including academics, early career researchers, students, educational practitioners and policymakers, of the background and contribution of the Special Issue. It is divided into four parts. In the first part, we explain why social inequalities in civic and political engagement are problematic. In the second part, we focus on a review based on the existing research to explore what has been done concerning education, particularly citizenship education, to promote the citizenship outcomes of disadvantaged youth and mitigate social inequalities in such outcomes. The third part will introduce the published Special Issue papers and emphasise how these papers contribute to the field. Finally, we highlight the following steps and future directions for the area.

\section{Social Inequalities, Learning Opportunities, and Political Participation}

For a democracy to function optimally, ideally, all individuals and social groups make equal use of the opportunities to influence political decision-making (Levinson 2010; Hoskins and Janmaat 2019; Hoskins et al. 2021; Janmaat 2020). In view of this argument, there is no justifiable reason that certain groups are participating at lower levels and are heard less within political debates. Yet, social inequalities in political participation are one of the most conspicuous and persistent features of western societies, undermining the responsiveness and representativeness of their democracies (Bartels 2008; Dalton 2017; Donbavand and Hoskins 2021; Hoskins et al. 2017, 2021; Janmaat 2020; Peters and Ensink 2015). As a rule, people of disadvantaged backgrounds do not vote, take part 
in demonstrations or are otherwise politically active to the same degree as people from more privileged families (Deimel et al. 2020; Hoskins and Janmaat 2019; Janmaat 2020). Consequently, their needs and responsibilities are less likely to be considered by the democratically elected government, which further reinforces the formers' disappointment with democracy and alienation from the democratic process (Hoskins et al. 2021; Janmaat 2020; Verba et al. 1995).

Hoskins and Janmaat (2019) found that education systems play a crucial role in generating and sustaining these inequalities. They do so primarily by not offering equal access to learning opportunities to become politically engaged. Time and again, young people from working-class families report lower levels of involvement in school councils, political discussions and other learning strategies that previous research has found to be particularly conducive for political engagement. At the same time, existing research has shown that when disadvantaged youth do use such learning opportunities, they often benefit more from them, in terms of enhanced political engagement levels, than children from privileged families (Gainous and Martens 2012; Hoskins et al. 2017, 2021). As disadvantaged youth have lower levels of political engagement to begin with, such learning opportunities allow them to "catch up" with their privileged peers (they are thus said to have "compensatory effects"). Hence, there is every reason to reform the education system in ways that genuinely achieve equal access to civic learning opportunities. In the next section, we review several of these learning opportunities in terms of how effective they are in enhancing political engagement in general and promoting that of disadvantaged youth in particular.

\subsection{Fostering Civic and Political Participation via Learning Approaches}

Citizenship education (CE) has been long expected and utilised to reduce social inequality and foster civic and political participation, by providing all young people with equal access to learning resources to engage them politically, regardless of social-economic backgrounds (Deimel et al. 2020; Donbavand and Hoskins 2021; Hoskins et al. 2017; Hoskins and Janmaat 2019). As noted above, the access to learning for disadvantaged youth allows them to catch up on their political learning and compensate for the negative impact of their political learning experiences at home (i.e., less chance to develop basic political understanding due to less educated and political engaged parents), which has been labelled as education's compensating effect (Campbell 2008). But on the other side of the coin, privileged students have greater opportunities to develop political competence at home, which in turn could help them take greater advantage of the learning opportunities held at schools (Hoskins and Janmaat 2019). Seen in this sense, schools can also accelerate social inequalities in political engagement between disadvantaged and advantaged peers.

This paper will explore the literature that has investigated the relationship between school-based learning opportunities and political participation. The underlying reason for emphasising school is that young people in this age group may have little direct contact and experience with a democratic government and only know about it through discussions in school and at home (Torney-Purta et al. 2004). Regarding the school's role in promoting young people's civic and political participation, Hoskins and Janmaat (2019) have discussed two learning theories. Firstly, the cognitive theory highlights the significance of the transferral and acquisition of knowledge about politics through lessons about the political system for example. Secondly, the participatory approach places heavy emphasis on developing young people's engagement via democratic participation, for instance, by debating a topic in an open climate of classroom discussions or by joining a student or school council. Through the participating process, young people exchange and co-construct their political knowledge, build up an identity in the group, and learn to achieve a common target by collaborating with their peers (Hoskins and Janmaat 2019). Inspired by these learning theories, Hoskins and Janmaat (2019) identified five school-based learning opportunities, including three $\mathrm{CE}$ related opportunities-CE as an individual subject, $\mathrm{CE}$ as a cross-curriculum component, teachers' preparedness and training-and 
two participatory learning opportunities-open classroom climate and civic participation. In what follows, we will briefly review the existing literature regarding the diverse learning opportunities suggested by Hoskins and Janmaat (2019).

\subsubsection{Citizenship Education as an Individual Subject}

As mentioned previously, citizens from privileged backgrounds are more inclined to engage in democratic politics than people from disadvantaged ones. CE has been suggested to potentially play a role in boosting students' positive attitudes towards civic and political engagement (Keating et al. 2015). For instance, in 2002 the UK government introduced compulsory citizenship lessons in schools to enhance what was perceived to be lagging political engagement levels in young people (see Crick 1998). Regarding the role of CE in youth's political outcomes, many studies from a variety of national contexts show that the students who have taken formal CE are more likely to vote in the future (McDevitt and Kiousis 2006; Hoskins and Janmaat 2019), and demonstrate higher levels of civic knowledge and skills compared to those who have not experienced CE (for the UK, see Brown 2012; Kerr 2014; Pontes et al. 2019; for Australia, see Lindström 2010; for the United States, see Patterson et al. 2012, and for Israel, see Court and Abbas 2010). However, concerns about the efficiency of CE have also been expressed by a few empirical studies (Donbavand and Hoskins 2021; Goodwin et al. 2010; Green et al. 2011). One of the main critiques about the efficiency of CE is that it overly stresses individuals' formal and abstract citizenship knowledge and skills development, rather than placing students in the context beyond the classroom to develop more realistic knowledge and solve real-world problems in the local communities (Pontes et al. 2019). This is in line with the increased attention to participatory learning approaches, such as open classroom climate and civic participation at schools (Hoskins et al. 2012; Hoskins and Janmaat 2019), which will be discussed later.

\subsubsection{Citizenship Education as a Cross-Curriculum}

In some jurisdictions, schools have the autonomy to have CE as a stand-alone subject or run it across the curricula (Donbavand and Hoskins 2021). Is this approach a helpful strategy to foster young people's civic and political participation? The results from the empirical research are inconclusive. By drawing upon an integrated ICCS 2009 datasets based on six European countries, Hoskins and Janmaat (2019) have found that CE has a cross-curricular component, weakly but negatively related to all forms of participation outcomes (both conventional, i.e., voting, legal protest, formal participation and radical, i.e., illegal protest), which implies that this form of learning might not contribute to young people's civic and political participation. In stark contrast, the randomised control trial article reviewed by Donbavand and Hoskins in this Special Issue by Condon and Wichowsky (2018) reported different results. Drawing upon 551 grade 6-8 students in 13 American schools, Condon and Wichowsky (2018) found the intervention that combines science and civic instruction in a unit about community and family water conservation contributes to students' engagement in both science and civics, with the support of teacher professional development and technology-based tools. Nevertheless, there is a considerable difference between measuring one specific and targeted cross-curricular programme with analysis of schools that have simply ticked a box in a survey that this is the method applied in their school for citizenship education. It may be that there is very little citizenship education happening at all in these schools.

\subsubsection{Citizenship Education as a Whole-School Approach}

Donbavand and Hoskins (2021) review for this Special Issue demonstrated the potential of the whole-school approach. This approach is where the whole-school ethos and mission are orientated towards developing young active citizens and the curricular and extra-curricular activities all flow from this stance. The results of the randomised control trial demonstrated significant increases in the chance of future voting for those young people who attended this school (Gibb 2016). 


\subsubsection{Teachers' Preparedness and Training}

Effective teaching approaches and learning methods are suggested to be the most important factors to bring the best civic and political learning outcomes (Crick 1998; Donbavand and Hoskins 2021). Teaching about citizenship includes leading debates on controversial issues and developing open and enlightened classroom discussions (Crick 1998). Teachers are the persons who are responsible for establishing a secure classroom climate, in which all students are open and willing to express points of view which disagree with those held either by their peers or teachers. A capable teacher is the one who is aware of the potential problems and receives professional training on seeking a balanced, fair and objective approach to engaging students to debate controversial issues (Crick 1998). In contrast, teachers who have received very little training on teaching citizenship may feel less confident to lead discussions on controversial issues. Donbavand and Hoskins (2021) reviewed two experimental studies which predict that investing in the training and preparedness of teachers makes a difference in students' civic and political outcomes (see Andersson et al. 2013; Barr et al. 2015). Similar findings and recommendations also noted in papers published within the Special Issue (see Babhoutak et al. 2020; Coopmans et al. 2020; Kunitsõn and Kalev 2021; Rinnooy Kan et al. 2021). In this sense, it is necessary to emphasise teachers' differences in the capabilities and responsibilities of delivering such programmes and their consequences on students' civic and political learning. Besides, teachers also play an essential role in monitoring and evaluating students' learning outcomes in CE. Day-to-day assessment of students' learning in citizenship education via a range of forms, such as observation, listening, and appraising students' written tasks, allows teachers to clarify learning objectives and follow up with the progress students have made in the learning outcomes (Crick 1998).

\subsubsection{Open Classroom Climate}

As one of the most frequently mentioned participatory methods of civic learning, an open climate of classroom discussions ensures a supportive environment for students to discuss a wide array of social and political problems with classmates and teachers. In such an environment, students are encouraged to bring forward social and political issues in which they have an interest and openly express their attitudes (i.e., agree or disagree) toward classmates and teachers. Students then build and co-construct knowledge and may feel that they are a part of the community. Numerous studies have drawn on cross-sectional and longitudinal data suggest that students who report engaging in more issues-related discussions in a safe and free classroom were more likely to participate more in politics (Hoskins et al. 2012; Hoskins and Janmaat 2019; Hoskins et al. 2021; Knowles et al. 2018; Torney-Purta 2002), demonstrate positive attitudes towards political engagement (Geboers et al. 2013), obtain higher levels of civic and political knowledge (McDevitt and Kiousis 2006) and skills (Finkel and Ernst 2005). Nevertheless, using regression analysis on the Citizenship Education Longitudinal (CELS) data, Hoskins et al. (2017) found that disadvantaged students have significantly less access to this learning opportunity than their peers from more privileged backgrounds. The underlying reason could be that children of low SES background have less chance of developing and exercising political knowledge, skills, and attitudes with educated parents at home, which in turn results in less political interests and lower confidence to be involved in classroom debates and discussions, compared to their peers from more advantaged backgrounds. Furthermore, an open classroom climate is more of a learning process than a specific activity, which means it is inevitably more challenging to ensure that all students feel engaged (Hoskins et al. 2017). Besides, students are already picking up from school, home, outside school communities some knowledge of what social and political problems affect them, and these learning experiences also have an added effect on their engagement in an open classroom climate. 


\subsubsection{Civic Participation at School}

A school with a participatory environment usually allows students to develop citizenship practices and increase confidence in their ability to effectively engage while at school and/or even while in the broader community (Campbell 2008; Hart et al. 2007; Mayne and Hakhverdian 2017). Participation in a voluntary group involves members interacting and negotiating within the community, doing things together toward a common learning goal, negotiating new meanings, and learning from each other's experiences. Through teamwork and conflict resolution, students learn to respect others, distribute their talents, balance self-interest and the common good and develop their identity (Youniss and Yates 1997; Torney-Purta 2002). Such a participating experience entails students' feeling of belonging to the school and a sense of security; in return, they may be more inclined to participate in the future.

This form of learning has been empirically tested to be a helpful strategy to develop conventional forms of participation in most places (Hoskins and Janmaat 2019; Keating and Janmaat 2016). Additionally, the empirical evidence based on ICCS 2009 and 2016 Nordic countries data suggests the vital role of civic participation at school in compensating for missed political socialisation in the family for students of disadvantaged backgrounds (Hoskins et al. 2021).

\subsection{Learning Opportunities, Political Participation, and Social Inequality}

As the previous paragraphs show, school works as the primary mechanism of delivering $\mathrm{CE}$ and facilitating participatory activities to prepare capable young people for politics. Overall, the findings on the role of citizenship education in reducing social gaps in engagement are inconclusive. The empirical results in Hoskins and Janmaat (2019), who drew on pooled ICCS data of the six European countries (England, Switzerland, Ireland, Sweden, Italy, Poland), suggest that all these learning opportunities cannot reduce social gaps in engagement. Deimel et al. (2020), however, showed that formal citizenship education reduces the link between young people's SES status and intended electoral participation in Denmark, Germany and Netherlands, which suggests that CE has a compensation effect. In a similar vein and focusing on the Nordic countries, Hoskins et al. (2021) noted that when disadvantaged students obtained access to civic learning, they seemed to benefit as much or more from the participating experience compared to their counterparts from more advantaged backgrounds. Authors highlighted that civic participation at school is an influential factor that can be used to diminish the social gaps and develop students' future electoral participation and civic knowledge for those underprivileged students (2021). These findings tally with Janmaat et al. (2014)'s proposition that the participation gap might be smaller in comprehensive education systems.

\section{Contributions in the Special Issue}

This Special Issue is comprised of seven journal papers. It contributes to the field by offering more empirical evidence as to the effective ways in which education can reduce social gaps in civic and political engagement. Within the Special Issue, three papers focusing on the school's role in developing young people's citizenship competence, such as knowledge, skills, interests and attitudes towards diversity. Two articles look at exclusion/minority groups cases, indicating valuable lessons to develop tailored educational materials and/or activities for the hard-to-reach groups. As a unique contribution, two more papers emphasise experimental studies: the paper written by Steven Donbavand and Bryony Hoskins provides a comprehensive and systematic review of all the experimental designs on promoting political participation; while the one written by Sven Ivens \& Monika Oberle unpacks some details on how a digital intervention operates and improves to produce satisfying outcomes. In the paragraphs that follow, these papers are briefly introduced.

The article "Exclusion and Antisystem Attitudes: The Impact of Perceived Discrimination in Attitudes towards Democracy and Willingness to Use Violence among Adolescents 
in Brussels" by Elham Mansoury Babhoutak, Dimokritos Kavadias, and Nohemi Jocabeth Echeverria Vicente, explores the political consequences of social inequality and exclusion for adolescents. Drawing upon the data of 1789 Grade 10 students (average age is 16) from 24 schools in Brussels, the article uses multilevel analysis and finds that adolescents' perceived discrimination, specifically at school, is significantly related to their anti-democratic attitude and their willingness to use violence. Authors have raised the concern that the perceived discrimination and anti-system attitudes may drive young people to stay away from politics and threaten social cohesion. As school is where students spend a great deal of time, this paper recommends that future research be conducted to explore what and which school-level predictors, such as teacher-student relationship and school environment, affect adolescents' perceived discrimination.

Relevantly, Rinnooy Kan, Willemijn F., Virginie März, Monique Volman, and Anne Bert Dijkstra, in the article "Learning from, through and about Differences: A Multiple Case Study on Schools as Practice Grounds for Citizenship", moves to explore how students' relations with teachers and peers affect their citizenship development. Drawing upon data collected from multiple resources, including document analysis, observations, and semi-structured interviews in four Dutch secondary schools, this paper investigates how school functions as a practice ground for young people's learning of dealing with diversity. The authors demonstrate that the reflection on the enactment of 'dealing with differences' was mainly focused on students' individual characteristics in all surveyed schools. The difference within and between schools, for example, the difference between students and teachers, and between a school's student population and the broader societal context, were underexplored within the field. Taking these into consideration, this paper highlights the importance of preparing teachers to consider a wider array of differences to practice dealing with diversity with their students and encourage students to reflect on the societal implications of being different from others.

Then, the article "Towards a Comprehensive School Effectiveness Model of Citizenship Education: An Empirical Analysis of Secondary Schools in The Netherlands" by Coopmans et al., examines the role of a school in promoting students' citizenship competence. Using cross-sectional data from students, teachers, team and school leaders at 78 secondary schools, the article adopted multilevel structural equation models to analyse direct and indirect school-level determinants of students' citizenship competence, including knowledge, attitudes and self-reported skills. The empirical results largely confirmed the previous literature and found that schools' attention to citizenship education and open classroom climate positively affected students' citizenship competence. Interestingly, different teaching practices were found to be associated with different outcomes: when teachers frequently play the monitoring role at school, the students were found to report low levels of competence; in contrast, when teachers encouraged students to actively choose the topic to discuss at class, students demonstrated high levels of citizenship competences. In alignment with Rinnooy Rinnooy Kan et al. (2021)'s recommendations, this paper noted that teachers should be encouraged to train in more specific citizenship knowledge to function well when working with students.

As mentioned earlier in this section, this Special Issue includes two papers which specially focus on minority group cases. Nikolai Kunitsõn \& Leif Kalev in their article "Citizenship Education Policy: A case of Russophone Minority in Estonia", has used content analysis and semi-structured interviews to tackle the issue of the ethnic socialeconomic inequality between communities in Estonia and investigated how citizenship education can be used to diminish gaps in the future. Through analysing the national CE and cross-curricular curriculums, the authors found that the general aims are clearly set up (to develop active citizens), but the implementation mainly relies on teachers' capability and willingness of delivering courses. Those teachers in the interviews reported the heavy teaching workload and expressed the concern of lacking support and training from their schools. Additionally, the CE curriculums place an over-emphasis on civic and political knowledge that leaves skills and values little addressed. Teachers confirmed this and 
mentioned that the in-class activities provided students with even more knowledge but failed to engage them to practice and exercise their roles as a citizen. There are also minimum participating opportunities for students outside the classroom, as the connection to local communities, government and politics largely depends on teachers' personal contacts. Besides this, the authors also highlight the impact of a wide range of factors, such as social media, less homogeneous social environments, and teachers' differences, on students' civic learning outcomes. In response, the authors recommend: (a) promoting a common and united education system for students who speak different native languages to reduce segmentation; (b) adding practical elements when designing the CE curriculums; (c) supporting and training teachers to engage students with interactive methods.

Further, Monika Oberle and Märthe-Maria Stamer in the project report, "Reaching the Hard-To-Reach with Civic Education on the European Union: Insights from a German Model Project", present the details of a workshop designed for hard-to-reach youth and concludes with practical methods for improving civic education on the European Union (EU). The workshop adopted a learner-centred approach at each stage: on day one, participants were encouraged to bring topics to discuss, build links between themselves and the EU, and be familiarised with the basic knowledge and information-search on the EU; On day two, participants utilised the knowledge learned from day one to participate in a simulation game to examine decisions regarding plastic pollution at the European level. The effectiveness of the work was then assessed by participants' pre-/post-/follow-up questionnaires on workshop methods and materials. It must be kept in mind that this project is ongoing, and therefore is without evaluation results. Nevertheless, the detailing of this workshop contributes to learner-centred approaches that many will find useful, through the provision of concepts and materials tailored to these hard-to-reach groups.

Finally, there are two papers focusing on the experimental study. The review of the experimental studies written by Steven Donbavand and Bryony Hoskins, "Citizenship Education for Political Engagement: A Systematic Review of Controlled Trials", identified 25 studies that use controlled trials to investigate the causal relationship between Citizenship Education Programmes and young people's political engagement outcomes. The findings of the review confirmed that (a) quality teacher training is key to underpinning the school-based citizenship education, no matter if it is a stand-alone programme, a crosscurricular one, or a whole-school approach; (b) participatory approaches to teaching are the most effective and have the overwhelming advantage of connecting with young people's motivation than the traditional acquisition-based approaches. This applies to all forms of citizenship education; (c) online citizenship education learning is prevalent at the moment, although the findings of its impact on young people's offline attitudes and behaviours are mixed. The positive results yielded from the studies showed that the digital world shares similarities with the offline world, in that where the students are involved in developing their own content, the changes in attitudes and behaviours are most pronounced.

The other experimental study, "Does Scientific Evaluation Matter? Improving Digital Simulation Games by Design-Based Research", by Sven Ivens \& Monika Oberle, is a timely response to the emergence of online citizenship education learning. This study used longerterm evaluation data to identify and fix problems that existed in educational interventions. After comparing the last (2019/2020) and first (2015/2016) evaluation cycle, the overall performance of the simulation game is improved in its effectiveness in transferring EU knowledge and enhancing users' overall satisfaction with the game (Ivens and Oberle 2020). This study stressed the value of the design-based research approach for designing and developing educational interventions, which provides some evaluation lessons for the future implementation of digital simulation games.

\section{Conclusions and Implications}

To summarise, the seven papers measured and evaluated a wide range of CE programmes and activities (formal \& informal CE, digital citizenship learning), which yielded 
some beneficial strategies for future research to prepare youth, especially disadvantaged students, for participation in politics:

1. All school-based papers within this Special Issue highlight the importance of providing teachers with sufficient support, such as learning resources, tools and professional training for teaching CE or CE-related courses. Teachers' preparedness and training in citizenship education are essential for boosting their confidence and quality in delivering the subject. A well-trained teacher could help students to develop a greater understanding of the subject.

2. Regardless of the forms of the learning (formal, informal, online, etc.), two things are found to promote students' participation: (a) adopting a participatory practice method to extend students' civic learning and participation beyond the classroom into the local communities. Students, especially those of disadvantaged backgrounds, will feel empowered by solving a real-world problem and enjoy their voice being heard by the public. This also helps students build up social and moral responsibility and realistic knowledge and skills to participate in real-life contexts; (b) developing a student-centred learning format brings positive civic and political learning outcomes. This does not only reflect on the teaching methodology itself but also somewhat stresses that the relationship between students, teachers, and schools is critical. A supportive, accessible, and trustworthy environment allows students to develop an identity and participate more in the activities held at schools.

3. The demands for citizenship learning and communicating online were continuously rising during the pandemic. Future research could therefore focus on supporting the development of digital citizenship and engagement on social media and perceive how other learning opportunities can boost or diminish students' digital citizenship.

Author Contributions: All authors have participated in all sections. All authors have read and agreed to the published version of the manuscript.

Funding: This research was funded by EU Cost Action Young-In, grant number CA17114.

Institutional Review Board Statement: Not applicable.

Informed Consent Statement: Not applicable.

Data Availability Statement: Not applicable.

Conflicts of Interest: The authors declare no conflict of interest.

\section{References}

Andersson, Klas, Sverker C. Jagers, Annika Lindskog, and Johan Martinsson. 2013. Learning for the future? Effects of education for sustainable development (ESD) on teacher education students. Sustainability 5: 5135-52. [CrossRef]

Babhoutak, Elham Mansoury, Dimokritos Kavadias, and Nohemi Jocabeth Echeverria Vicente. 2020. Exclusion and antisystem attitudes: The impact of perceived discrimination in attitudes towards democracy and the willingness to use violence among adolescents in Brussels. Social Sciences 9: 175. [CrossRef]

Barr, Dennis, Beth Boulay, Robert Selman, Rachel McCormick, Ethan Lowenstein, Beth Gamse, Melinda Fine, and M. Brielle Leonard. 2015. A randomized controlled trial of professional development for interdisciplinary civic education: Impacts on humanities teachers and their students. Teachers College Record 117: 1-52.

Bartels, Larry M. 2008. Unequal Democracy: The Political Economy of the New Gilded Age. Princeton: Princeton University Press.

Brown, Jane. 2012. Citizens fit for the 21st century? The role of school design in facilitating citizenship and self-governance in young people. Education, Citizenship and Social Justice 7: 19-31. [CrossRef]

Campbell, David E. 2008. Voice in the classroom: How an open classroom climate fosters political engagement among adolescents. Political Behavior 30: 437-54. [CrossRef]

Condon, Meghan, and Amber Wichowsky. 2018. Developing citizen-scientists: Effects of an inquiry-based science curriculum on STEM and civic engagement. The Elementary School Journal 119: 196-222. [CrossRef]

Coopmans, Manja, Geert Ten Dam, Anne Bert Dijkstra, and Ineke Van der Veen. 2020. Towards a comprehensive school effectiveness model of citizenship education: An empirical analysis of secondary schools in the Netherlands. Social Sciences 9: 157. [CrossRef]

Court, Deborah, and Randa Abbas. 2010. Role of Druze high schools in Israel in shaping students' identity and citizenship. Education, Citizenship and Social Justice 5: 145-62. [CrossRef] 
Crick, Bernard. 1998. Education for Citizenship and the Teaching of Democracy in Schools. Final Report. London: Qualifications and Curriculum Authority, September 22.

Dalton, Russell J. 2017. The Participation Gap: Social Status and Political Inequality. Oxford: Oxford University Press.

Deimel, Daniel, Bryony Hoskins, and Hermann J. Abs. 2020. How do schools affect inequalities in political participation: Compensation of social disadvantage or provision of differential access? Educational Psychology 40: 146-66. [CrossRef]

Donbavand, Steven, and Bryony Hoskins. 2021. Citizenship education for political engagement: A systematic review of controlled trials. Social Sciences 10: 151.

Finkel, Steven E., and Howard R. Ernst. 2005. Civic education in post-apartheid South Africa: Alternative paths to the development of political knowledge and democratic values. Political Psychology 26: 333-64. [CrossRef]

Gainous, Jason, and Allison M. Martens. 2012. The effectiveness of civic education: Are "good" teachers actually good for "all" students? American Politics Research 40: 232-66. [CrossRef]

Geboers, Ellen, Femke Geijsel, Wilfried Admiraal, and Geert Ten Dam. 2013. Review of the effects of citizenship education. Educational Research Review 9: 158-73. [CrossRef]

Gibb, Natalie. 2016. Getting Climate Ready: A Guide for Schools on Climate Action and the Whole-School Approach. Pairs: UNESCO, Available online: https:/ / unesdoc.unesco.org/ark:/48223/pf0000246740 (accessed on 20 September 2021).

Goodwin, Matthew J., Stephen Greasley, Peter John, and Liz Richardson. 2010. Can we make environmental citizens? A randomised control trial of the effects of a school-based intervention on the attitudes and knowledge of young people. Environmental Politics 19: 392-412. [CrossRef]

Green, Donald P., Peter M. Aronow, Daniel E. Bergan, Pamela Greene, Celia Paris, and Beth I. Weinberger. 2011. Does knowledge of constitutional principles increase support for civil liberties? Results from a randomized field experiment. The Journal of Politics 73 : 463-76. [CrossRef]

Hart, Daniel, Thomas M. Donnelly, James Youniss, and Robert Atkins. 2007. High school community service as a predictor of adult voting and volunteering. American Educational Research Journal 44: 197-219. [CrossRef]

Hoskins, Bryony, and Jan Germen Janmaat. 2019. Education, Democracy and Inequality: Political Engagement and Citizenship Education in Europe. Basingstoke: Palgrave Macmillan.

Hoskins, Bryony, Jan Germen Janmaat, and Ernesto Villalba. 2012. Learning citizenship through social participation outside and inside school: An international, multilevel study of young people's learning of citizenship. British Educational Research Journal 38: 419-46. [CrossRef]

Hoskins, Bryony, Jan Germen Janmaat, and Gabriella Melis. 2017. Tackling inequalities in political socialisation: A systematic analysis of access to and mitigation effects of learning citizenship at school. Social Science Research 68: 88-101. [CrossRef] [PubMed]

Hoskins, Bryony, Lihong Huang, and Cecilia Arensmeier. 2021. Socioeconomic inequalities in civic learning in Nordic Schools: Identifying the potential of in-school civic participation for disadvantaged students. In Northern Lights on Civic and Citizenship Education: A Cross-National Comparison of Nordic Data from ICCS. Cham: Springer, pp. 93-122.

Ivens, Sven, and Monika Oberle. 2020. Does scientific evaluation matter? Improving digital simulation games by design-based research. Social Sciences 9: 155. [CrossRef]

Janmaat, Jan Germen. 2020. School social segregation and social inequalities in political engagement among 16 to 20 year olds in fourteen countries. Research Papers in Education 35: 1-22. [CrossRef]

Janmaat, Jan Germen, Tarek Mostafa, and Bryony Hoskins. 2014. Widening the participation gap: The effect of educational track on reported voting in England. Journal of Adolescence 37: 473-82. [CrossRef] [PubMed]

Keating, Avril, and Jan Germen Janmaat. 2016. Education through citizenship at school: Do school activities have a lasting impact on youth political engagement? Parliamentary Affairs 69: 409-29. [CrossRef]

Keating, A., A. Green, and G. Janmaat. 2015. Young Adults and Politics Today: Disengaged and Disaffected or Engaged and Enraged? The Latest Findings from the Citizenship Education Longitudinal Study (CELS). London: University College London Institute of Education.

Kerr, David. 2014. Enhancing the political literacy of young people: A shared responsibility. In Beyond the Youth Citizenship Commission: Young People and Politics. London: Political Studies Association, pp. 44-47.

Knowles, Ryan T., Judith Torney-Purta, and Carolyn Barber. 2018. Enhancing citizenship learning with international comparative research: Analyses of IEA civic education datasets. Citizenship Teaching E Learning 13: 7.

Kunitsõn, Nikolai, and Leif Kalev. 2021. Citizenship educational policy: A case of Russophone minority in Estonia. Social Sciences 10: 131. [CrossRef]

Levinson, Meira L. 2010. The civic empowerment gap: Defining the problem and locating solutions. In Handbook of Research on Civic Engagement in Youth. Edited by L. Sherrod, J. Torney-Purta and C. Flanagan. Hoboken: Wiley, pp. 331-62.

Lindström, Lisbeth. 2010. Youth citizenship and the millennium generation. Citizenship, Social and Economics Education 9: 48-59. [CrossRef]

Mayne, Quinton, and Armen Hakhverdian. 2017. Education, socialization, and political trust. In Handbook on Political Trust. Cheltenham: Edward Elgar Publishing.

McDevitt, Michael, and Spiro Kiousis. 2006. Experiments in Political Socialisation: Kids Voting USA as a Model for Civic Education Reform. CIRCLE Working Paper 49. Washington, DC: The Center for Information and Research on Civic Learning and Engagement (CIRCLE), University of Maryland. 
Patterson, Nancy, Frans Doppen, and Thomas Misco. 2012. Beyond personally responsible: A study of teacher conceptualizations of citizenship education. Education, Citizenship and Social Justice 7: 191-206. [CrossRef]

Peters, Yvette, and Sander J. Ensink. 2015. Differential responsiveness in Europe: The effects of preference difference and electoral participation. West European Politics 38: 577-600. [CrossRef]

Pontes, Ana Isabel, Matt Henn, and Mark D. Griffiths. 2019. Youth political (dis) engagement and the need for citizenship education: Encouraging young people's civic and political participation through the curriculum. Education, Citizenship and Social Justice 14: 3-21. [CrossRef]

Rinnooy Kan, Willemijn F., Virginie März, Monique Volman, and Anne Bert Dijkstra. 2021. Learning from, through and about differences: A multiple case study on schools as practice grounds for citizenship. Social Sciences 10: 200. [CrossRef]

Torney-Purta, Judith. 2002. The school's role in developing civic engagement: A study of adolescents in twenty-eight countries. Applied Developmental Science 6: 203-12. [CrossRef]

Torney-Purta, Judith, Carolyn Henry Barber, and Wendy Klandl Richardson. 2004. Trust in government-related institutions and political engagement among adolescents in six countries. Acta Politica 39: 380-406. [CrossRef]

Verba, Sidney, Kay Lehman Schlozman, and Henry E. Brady. 1995. Voice and Equality: Civic Voluntarism in American Politics. Cambridge: Harvard University Press.

Youniss, James, and Miranda Yates. 1997. Community Service and Social Responsibility in Youth. Chicago: University of Chicago Press. 